\author{
Iryna BABETS, \\ Ivan MYTSENKO, \\ Valerii MYTSENKO
}

\title{
FOREIGN DIRECT INVESTMENT: STRUCTURAL CHANGES \\ AND IMPACT ON UKRAINE'S ECONOMIC SECURITY
}

\begin{abstract}
The article presents assessment of the level of investment security of Ukraine during 2006-2018. Most influential factors of the country's investment security have been identified. They include structure of foreign direct investment (FDI), particularly its high research intensity. It has been identified that the integral indicator of investment security is highly sensitive to the change in the investment share of high-tech industries in total FDI volumes.

The regression analysis has confirmed significant influence of structural changes in foreign direct investment on the state of macroeconomic security of Ukraine during 2006-2018. The inverse relationship between unemployment rate

(C) Iryna Babets, Ivan Mytsenko, Valerii Mytsenko, 2020.

Babets Iryna, Doctor of Economics, Professor at the Department of International Economic Relations at Zaporizhzhya Institute of Economics and Information Technology, Ukraine. ORCID: 0000-00030635-9375

Mytsenko Ivan, Doctor of Economics, Professor, Head of the Department of International Economic Relations at Central Ukrainian National Technical University, Ukraine. ORCID: 0000-0002-2749-5117 Mytsenko Valerii, PhD of Pedagogy, Associate Professor, Head of the Department of Foreign Languages at Central Ukrainian National Technical University, Ukraine. ORCID: 0000-0001-6034-0224.
\end{abstract}



and impact on ukraine's economic security

and such indicators of FDI structure as investment share in high-tech industries and in metallurgical production has been identified. No correlation was found between unemployment rate and changes in the investment share in wholesale and retail trade, food, beverage and tobacco, information and telecommunications activities, financial activities and insurance in total FDI.

It is established that there is a close direct relation between GDP per capita and the change in the structure of FDI in the investment share in food, beverage and tobacco, information and telecommunications, financial and insurance. A strong direct relation between GDP growth rate and the change in total FDI share of investment in metallurgical industry and investment in high-tech industries was confirmed. A weak direct correlation is found between the Consumer Price Index and the shares in the FDI structure of investments in wholesale and retail trade and in high-tech industries. The inverse relationship is found between the Consumer Price Index and the share of investment in information and telecommunications activities in total FDI.

\section{Key words:}

Foreign Direct Investment, Investment Security, Integrated Indicator, Foreign Direct Investment Structure, Macroeconomic Security, Unemployment Rate, GDP, Consumer Price Index, High-Tech Industries.

JEL: E22, F47.

\section{Problem statement}

Overcoming the consequences of financial and economic crisis in Ukraine is complicated by the shortage of investment resources, which causes aggravation of threats to the economic security of the state due to the depreciation of fixed assets, limitation of innovative development opportunities, and continuation of raw material-oriented structure of industry. In the conditions of insufficient national capital investment, foreign direct investment becomes an important factor in the investment-innovation model of the economy, providing additional financial resources not only for the restructuring of the economy, for reconstruction and 
technical modernization of industrial enterprises, but also the development of services as the basis for building a post-industrial society.

Accordingly, the role of foreign direct investment in the formation of the investment component of the state economic security, which situation is determined by the degree of meeting the needs of the economic complex in capital investments is very essential. The situation is also determined by the degree of effective structure in the context of an innovative economy. The optimal level of investment security is the material basis for the realization of the state national interests, in particular economic growth and improving the quality of life of the population. In this regard, the need to solve the problems in the investment sphere makes the study of quantitative and qualitative indicators of foreign direct investment and its impact on the economic security of Ukraine of great importance.

\section{Literature review}

The publications of the Ukrainian scientists present the analysis of the trends of foreign investments in the Ukrainian economy and their structural disparities in the national economy distribution (Pereverzeva 2016; Timoshenko \& Liskovetska 2017). The works also include studies of the institutional factors of investment security and offer organizational and economic, information and legal mechanisms for improving the Institute of Property Law as the basis for the formation of stable conditions for investing foreign equity in Ukraine (Mokiy, Hurniak \& Datsko 2014). The problems of compliance of the indicators of investment security indicators to their optimal values; measures to create favourable investment climate and improvement of FDI in Ukraine taking into account interests of the national economic security in terms of European integration are considered in the works of D. Nikitenko (2017), K. Palyvoda (2018), S. Tkalenko (2019), O. Sharov (2015).

Despite the detailed scientific study of the trends and problems of foreign direct investment in the context of economic security, insufficient attention has been paid to the study of the structure of FDI and its impact on the state of investment security of Ukraine.

\section{Research objective}

The objective of the article is to determine the impact of structural changes in foreign direct investment on Ukraine's economic security. According to the objective, the following research objectives should be defined: (1) assessment and 

and impact on ukraine's economic security

analysis of the dynamics of the level of investment security of Ukraine taking into account qualitative changes in the structure of FDI; (2) analysis of trends in the structure of foreign direct investment in the Ukrainian economy; (3) identification of the impact of structural changes in FDI on the level of investment security and key macroeconomic security indicators of Ukraine.

\section{Research results}

Assessment of the situation in the sphere of state investment security begins with the formation of the system of indicators and obtaining estimates of their status on the basis of comparison of actual values of indicators calculated according to the official statistics with their threshold values. Taking into consideration the specifics of our study, the main task at this stage is to develop database of baseline indicators that would ensure correct calculation of the actual and threshold values of indicators that characterize the investment component of economic security, taking into account qualitative changes in the investment process, particularly in the structure of foreign direct investment.

The methodology of calculating the level of the state economic security includes a list of indicators of the situation in the state investment security. These are the degree of depreciation of fixed assets (\%); the ratio of the value of newly introduced fixed assets to the volume of capital investment (\%), the ratio of the investment volume to the value of fixed assets (\%); the ratio of investment in fixed capital to GDP (\%); the ratio of net FDI growth to GDP (\%); the share of foreign direct investment in total investment (\%) (Guidelines, 2007, 2013).

Well-known methodological approaches to the assessment of investment security do not take into account research intensity of investments and their sectoral structure, which is important to ensure the parameters of the investment process meet the criteria of economic security. Therefore, it is necessary to supplement the system of indicators with indicators that characterize the structure of investment by industries: the share of capital investment in high-tech industries in the total amount of capital investment (\%); the share of investment in high-tech industries in total FDI (\%).

At the same time, s special attention should be paid to determining the essence of the indicator " share of investments in high-tech industries in total FDl» from the viewpoint of security theory, taking into account the ambiguous impact of foreign direct investment on economic development. As a result, there is emergence of negative effects due to divergence in priorities of investment strategies of foreign investors with the national interests of the invested country. This causes a number of threats to the economic security of the state, particularly, the influence of foreign investors on the formation of investment markets in 
transformational economies and on the formation of development trends of invested industries in accordance with their own interests.

The risks associated with foreign direct investment also include: securing inefficient structure of national production with a predominance of old industrial sectors of economy; irrational use of the national raw material resource base and production capacities of increasing dependence on foreign capital; supply or sale of substandard, imperfect and outdated materials, components and processing equipment; withdrawal of profits abroad by investor.

Taking into consideration negative effects of foreign investment on the «host» country, it is important to mobile national resources for financing development of fixed assets, especially in industry. An increase in the share of FDI in the total volume of investment threatens to increase the country's dependence on foreign investors and exacerbate financial and economic crisis in case of « outflow» of foreign investment. Accordingly, in post-transformational economies, the level of foreign investment should not exceed certain thresholds.

For example, the ratio of net FDI growth to GDP should be in the range of $5-10 \%$, and the share of FDI in total investment should be in the range of 20$30 \%$. Thus, in terms of ensuring economic security and achieving national interests, there is an optimal range of values that characterize the amount of foreign capital in the country's economy. In addition, it is necessary to ensure optimal ratio of the attracted funds of foreign and domestic investors in the structure of investments in fixed capital.

It is advisable to set the threshold value of the investment share in hightech industries in the total FDI in the calculation of the integral index of investment security with the experience of the world at $5-10 \%$. At the same time, we will consider it as a two-threshold indicator, which is a stimulator only when its value is in the range from $5 \%$ to $10 \%$. If the value is less than $5 \%$ or larger than $10 \%$, it is considered as a stimulant because foreign direct investment in transition economies does not go along with the transfer of up-to-date technology to local producers.

Foreign investors locate in the host country manufacturing of the products, which are at the last stage of their life cycle and are produced on relatively outdated equipment. In addition, if foreign investors initiate and finance implementation of high-tech projects in the fields of fourth or fifth technological trend, it is preferable to obtain security documents for industrial property in Ukraine, consolidating their monopoly position in the production of certain goods. Therefore, in order to strengthen investment security, it is important to balance the desire to increase the volume of attracted investment and the need to channel them into high-tech industries in order to stimulate the demand for innovative products of the national producers. 
304 I r n a B a bets, I a n M y t se nko, va I e ríi M y t s e nko

Foreign direct investment: structural changes and impact on ukraine's economic security

Thus, to assess investment security of the state, it is advisable to use Methodology for calculating the level of economic security of Ukraine as a basic one. In order to obtain correct assessment results, it is necessary to improve the methodology in terms of the formation of the system of investment security indicators and the procedure for their rate setting. Taking into account current world tendencies of socio-economic development and the need to activate scientific and technological factors of economic growth in Ukraine, the list of indicators is supplemented with indicators that allow taking into account research intensity of investments.

The integral indicator of the state investment security is determined by the formula (Guidelines, 2007):

$$
I_{\text {IH.G. } \operatorname{sen}}=\sum_{i=1}^{b} a_{i} \times z_{i},
$$

where $a_{i}$ is weighting factors that determine the degree of contribution of $i$ indicator to the integral indicator of investment security; $z_{i}$ is normalized values of input indicators $x_{i}$.

Weighting coefficients $\left(a_{i}\right)$ are determined according to the Methodology for calculating the level of economic security of Ukraine by the method of principal components, which includes calculation of the correlation matrix; separation of main components and calculation of factor loadings; identification of principal components. To normalize actual values of the indicators of state investment security, the minimum (for the stimulus indicator) or the maximum value (for the stimulus indicator) of the corresponding indicator for the studied period was used as the normative value.

As a result of our calculations, investment security in Ukraine got worse in the long term, as it is shown in the decrease in the integral indicator from 0.865 in 2006 to 0.634 in 2018 (Table 1). Analysing the degree of compliance of the indicators with the criteria of economic security in the short term (normalized values), we can assume that a significant decrease in the level of investment security of Ukraine in 2016-2018 took place as a result of deterioration in such indicators as the ratio of the value of newly-introduced fixed assets to the volume of capital investment; the ratio of net growth of FDI to GDP, and the share of FDI in total investment.

It should be noted that the approximation to the lower limit of the optimal interval (5\%) of the indicator « the ratio of net FDI growth to GDP», which amounted $4,52 \%$ and $4,62 \%$ in $2015-2016$, respectively, cannot be explained by the increase in FDI. In contrast, FDI declined from 38.3 billion US Dollars in 2014 to 31.2 billion US Dollars in 2016, while reducing GDP significantly, from 122.1 billion US Dollars to 95.4 billion US Dollars respectively. Therefore, the conclusion about principal factors of investment security, which are based only on the analysis of the dynamics of indicators and changes in their degree of compliance with the criterion restrictions on economic security, are not sufficiently substantiated. 
Table 1

Normalized values of indicators and integral indicator of investment security of Ukraine in 2006-2018

\begin{tabular}{|c|c|c|c|c|c|c|c|c|c|}
\hline Year & 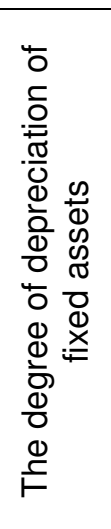 & 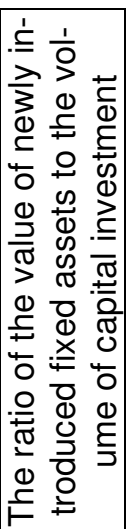 & 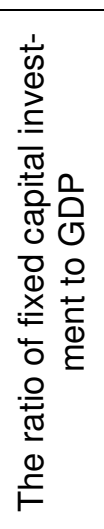 & 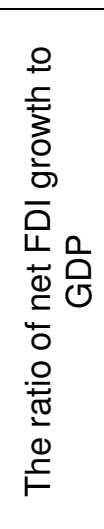 & 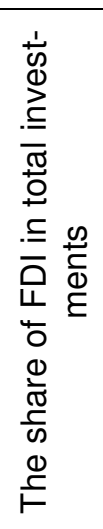 & 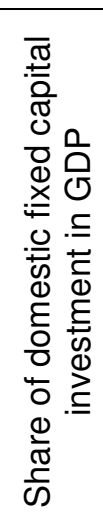 & 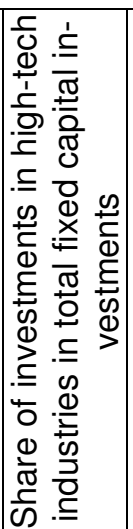 & 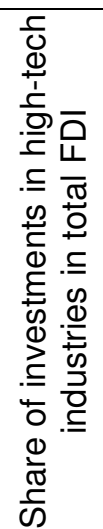 & 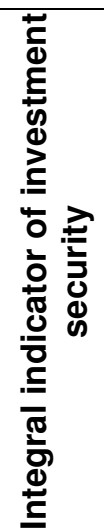 \\
\hline 2006 & 1 & 0,696 & 0,889 & 1 & 0,455 & 0,882 & 0,656 & 1 & 0,865 \\
\hline 2007 & 0,979 & 0,721 & 1 & 0,458 & 0,512 & 1 & 0,612 & 1 & 0,852 \\
\hline 2008 & 0,841 & 0,693 & 0,926 & 0,694 & 0,513 & 0,940 & 0,718 & 0,800 & 0,797 \\
\hline 2009 & 0,858 & 0,727 & 0,686 & 0,736 & 0,501 & 0,632 & 1 & 0,667 & 0,737 \\
\hline 2010 & 0,687 & 0,855 & 0,543 & 0,580 & 0,745 & 0,652 & 0,812 & 0,481 & 0,651 \\
\hline 2011 & 0,678 & 0,772 & 0,625 & 0,515 & 0,575 & 0,751 & 0,718 & 0,502 & 0,643 \\
\hline 2012 & 0,671 & 0,881 & 0,656 & 0,418 & 0,445 & 0,789 & 0,687 & 0,435 & 0,631 \\
\hline 2013 & 0,667 & 0,836 & 0,575 & 0,414 & 0,502 & 0,692 & 0,718 & 0,513 & 0,622 \\
\hline 2014 & 0,616 & 0,725 & 0,466 & 0,279 & 0,449 & 0,556 & 0,812 & 0,516 & 0,563 \\
\hline 2015 & 0,857 & 1 & 0,463 & 0,634 & 1 & 0,550 & 0,937 & 0,572 & 0,724 \\
\hline 2016 & 0,886 & 0,709 & 0,507 & 0,641 & 0,881 & 0,605 & 0,968 & 0,576 & 0,708 \\
\hline 2017 & 0,934 & 0,668 & 0,507 & 0,304 & 0,418 & 0,612 & 0,906 & 0,574 & 0,651 \\
\hline 2018 & 0,849 & 0,667 & 0,548 & 0,269 & 0,384 & 0,669 & 0,812 & 0,575 & 0,634 \\
\hline $\begin{array}{l}\text { Weigh- } \\
\text { ting coef- } \\
\text { ficients }\end{array}$ & 0,191 & 0,109 & 0,145 & 0,078 & 0,064 & 0,128 & 0,102 & 0,182 & - \\
\hline $\begin{array}{l}\text { Sensi- } \\
\text { tivity co- } \\
\text { efficients }\end{array}$ & 0,258 & 0,115 & 0,125 & 0,033 & 0,039 & 0,144 & 0,130 & 0,165 & - \\
\hline
\end{tabular}

Source: Calculated by the authors using the data of the State Statistics Service of Ukraine. 

and impact on ukraine's economic security

In order to determine most influential factors of investment security, we shall apply functional dependence of integral indicator of investment security of Ukraine on the set of indicators obtained in the process of data processing using principal components model in the «Statistics» software. The coefficient of sensitivity (elasticity) is calculated according to the approach of Russian scientists (Kibitkin \& Skoterenko 2010) by the formula:

$$
K_{u}=\frac{\Delta I_{I b}}{\Delta x_{i}} \cdot \frac{x_{i}}{I_{I b}},
$$

where $\Delta I_{I 5}$ is the difference between the actual value of integral indicator of investment security and the value of this indicator after changing actual value of the indicator by $1 \% ; \Delta x_{i}$ is the value of change in the actual value of indicator; $x_{i}$ is actual value of the indicator calculated on the basis of statistics; $I_{I Б}$ is the initial value of the integral indicator of investment security.

As can be seen from Table 1, in 2018, the highest sensitivity of integral indicator was observed before the change in the indicator « Degree of depreciation of fixed assets», since its decrease by $1 \%$ causes a decrease in the integral indicator by $0.258 \%$, all other things being equal. Since this indicator has increased from $55.1 \%$ in 2017 to $60.6 \%$ in 2018 , we can conclude that the impact of threats due to the excessive depreciation of fixed assets and aging of material base of enterprises has increased. From this point of view, the role of FDI in the development of high-tech industries is important, which significantly affects the level of investment security of Ukraine. This is confirmed by high sensitivity of the level of investment security to the change in the share of investment in high-tech industries in total FDI, that is an increase of the indicator by $1 \%$ contributes to the increase of the integral indicator by $0.165 \%$, all other things being equal.

In addition to these indicators, the investment security of Ukraine in 2018 was significantly influenced by changes in such indicators as: share of domestic fixed capital investment in GDP $\left(\mathrm{K}_{4}=0,144\right)$, the ratio of investment in fixed capital to GDP (Kч $=0,125)$, the share investments in high-tech industries in total fixed capital formation $(\mathrm{K} 4=0,130)$, the ratio of the value of newly introduced fixed assets to the amount of capital investment $(\mathrm{K} 4=0,115)$. At the same time, our assumption about the significant impact on the integral index of investment security of the change in the ratio of net FDI to GDP and the share of FDI in total investment was not confirmed, since the sensitivity coefficients are very low 0.033 and 0.039 , respectively.

Significant impact on the integral index of investment security of Ukraine and the change in the share of investments in high-tech industries in the total volume of FDI confirms the important role of changing the investment structure in shaping economic security of the state. For a more detailed study of the effects of structural changes in foreign direct investment, let us analyse the structure of FDI entering Ukraine by industries and economic activities. One third of all for- 
eign direct investment is directed to the Ukrainian industry, although over the period studied, its share decreased from $41.2 \%$ to $33.0 \%$. Also during $2010-2018$, there was a decrease in the share of investment in financial and insurance activities - from $25.3 \%$ to $11.15 \%$. A positive trend in terms of building a postindustrial society is an increase in the share of investment in infrastructure development, particularly in wholesale and retail trade (from 10.3\% to 16.7\%), information and telecommunications (from $3.8 \%$ to $6,8 \%$ ).

During the period under review, there have been significant changes in the structure of FDI in industry. While metallurgy was a priority area of foreign investment during 2010-2012, after 2013 the share of this sector in total FDI volumes declined gradually (Fig. 1). At the same time, the share of investments in the food industry doubled during the period under review. Investments in hightech industries (engineering, except repair and installation of machinery and equipment, and pharmaceutical production) do not exceed 3\% in total FDI, although there is a positive upward trend (from $2.16 \%$ in 2010 to $2.59 \%$ in 2018).

Figure 1

Foreign direct investment in the economy of Ukraine by selected industries (share of total FDI, \%)

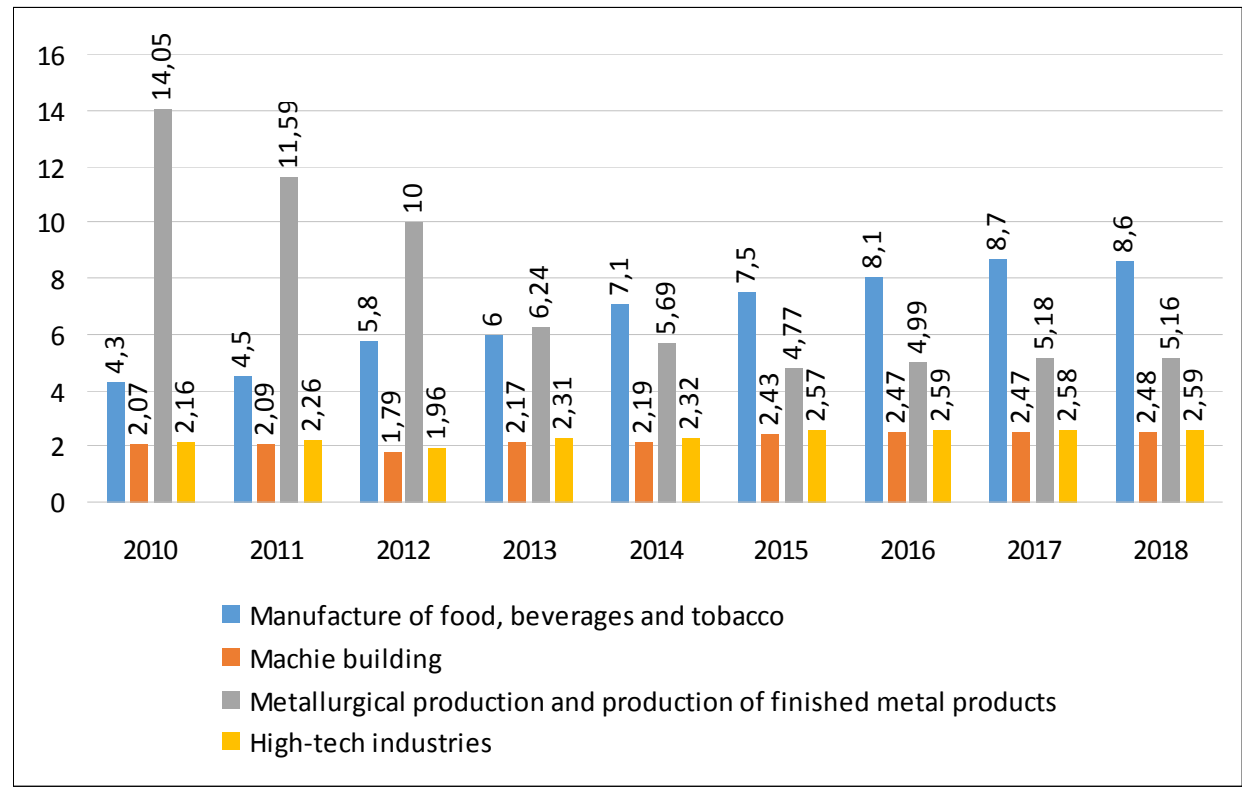

Source: Calculated by the authors using the date of the State Statistics Service of Ukraine. 

and impact on ukraine's economic security

Determining the impact of structural changes that have occurred in foreign direct investment on the economic security of Ukraine will be carried out by means of regression analysis of data from 2006 to 2018. In order to create a model, annual values of basic indicators of macroeconomic security of the state will successively be used as dependant variables. They are obtained from the database of the State Statistics Service of Ukraine: unemployment rate, GDP per capita, GDP growth rate, consumer price index.

Independent variables are the indicators that characterize the structure of foreign direct investment and are identified by the share of the respective sector of economic activity or industry in total FDI, calculated on the basis of the official statistics on the volume of foreign direct investment in Ukraine by types of economic activity (Table 2). Actual values of the indicators of macroeconomic security and structural changes in FDI over the period of 13 years have been taken the logarithm and regression using the software package «Statistica 7.0».

Table 2

Characteristics of variables of the research

\begin{tabular}{|c|c|c|c|}
\hline \multicolumn{2}{|c|}{$\begin{array}{l}\text { State macroeconomic } \\
\text { security indicators }\end{array}$} & \multicolumn{2}{|c|}{ Indicators of structural changes in FDI } \\
\hline $\begin{array}{l}\text { Denota- } \\
\text { tion }\end{array}$ & Name & Denotation & Name \\
\hline \multirow{2}{*}{ Unempl } & \multirow{2}{*}{$\begin{array}{l}\text { Unemploy- } \\
\text { ment rate, \% }\end{array}$} & invest_trade & $\begin{array}{l}\text { Share of investment in whole- } \\
\text { sale and retail trade, repair of } \\
\text { motor vehicles and motorcycles } \\
\text { in total FDI, \% }\end{array}$ \\
\hline & & invest_food_bev & $\begin{array}{l}\text { Share of investment in the pro- } \\
\text { duction of food, beverages and } \\
\text { tobacco in total FDI, \% }\end{array}$ \\
\hline \multirow[t]{2}{*}{$G D P \_p \_c$} & \multirow{2}{*}{$\begin{array}{l}\text { GDP per cap- } \\
\text { ita, thousand } \\
\text { UAH }\end{array}$} & invest_telecom & $\begin{array}{l}\text { Share of investment in informa- } \\
\text { tion and telecommunications ac- } \\
\text { tivities in total FDI, \% }\end{array}$ \\
\hline & & invest_high_tech & $\begin{array}{l}\text { Share of investment in high-tech } \\
\text { industries in total FDI, \% }\end{array}$ \\
\hline$G D P \_g \_r$ & $\begin{array}{l}\text { GDP growth } \\
\text { rate, } \%\end{array}$ & invest_metall & $\begin{array}{l}\text { Share of investment in metallur- } \\
\text { gical production and production } \\
\text { of finished metal products in to- } \\
\text { tal FDI, \% }\end{array}$ \\
\hline $\begin{array}{l}\text { Con- } \\
\text { sum_PI }\end{array}$ & $\begin{array}{l}\text { Consumer } \\
\text { Price Index, } \\
\%\end{array}$ & invest_fin_insur & $\begin{array}{l}\text { Share of investment in financial } \\
\text { and insurance activities in total } \\
\text { FDI, \% }\end{array}$ \\
\hline
\end{tabular}


The results of the regression analysis of the data (Table 3 ) show that there is a sufficient correlation between macroeconomic security indicators of Ukraine and the independent variables which characterize the structure of foreign direct investment in the national economy (the value $R$ is in the range from 0.6 to 0.9 ). The coefficient of determination indicates that the unemployment rate is more than $60 \%$ dependent on changes in the investment structure. In particular, the increase in FDI in high-tech industries and metallurgical production contributes to lower unemployment. The inverse relationship between these indicators can be traced over the long term.

Thus, the share of investment in the production of metallurgical products in total FDI decreased from $6.6 \%$ in 2006 to $5.2 \%$ in 2018, the share of investment in high-tech industries decreased from $4.5 \%$ to $2.6 \%$, respectively, and unemployment rate increased from $7.4 \%$ to $9.1 \%$. However, there is no link between unemployment rate and changes in the share of investment in wholesale and retail trade, food, beverage and tobacco, information and telecommunications, financial and insurance.

The regression results show a close relationship $(R=0.96)$ between GDP per capita and the independent variables characterizing the change in the share of investment in food, beverage and tobacco, information and telecommunications, financial and insurance in the structure of foreign direct investment. At the same time, GDP growth per capita in 2006-2018 (from 10.51 thousand UAH to 72.99 thousand $\cup A H)$ by $92 \%$ is caused by the change in these indicators $\left(R^{2}=\right.$ 0.92). In particular, in the period under review, the share of investment in food industry in total FDI volumes increased from $4.3 \%$ to $8.6 \%$, and the share of investment in information and telecommunications activities increased from $4.25 \%$ to $6.64 \%$. The share of investment in financial activities and insurance in the structure of FDI has not decreased significantly (from $11,42 \%$ to $11,15 \%$ ).

The slowdown in GDP growth from 107.6\% in 2006 to $103.4 \%$ in 2018 can largely be explained by a decrease in the total FDI share of investment in the metallurgical industry and investment in high-tech industries, since there is a strong link between these variables $\left(R=0.84, R^{2}=0.71\right)$. Considering positive impact of an increase in the share of investment in information and telecommunications activities, we can conclude that investing in this area has restrained the decline in GDP over the long term.

The direct dependence of economic growth in Ukraine on structural factors of foreign investment, revealed by our study, was particularly clearly observed in the crisis period of 2014-2015, when GDP growth declined to $93.4 \%$ and $90.2 \%$ and a decrease in the share of investment in the production of metallurgical products from $10 \%$ in 2013 to $5.68 \%$ in 2015 , in financial and insurance activities - from $22.8 \%$ to $16.7 \%$ respectively, and the share of investments in hightech industries remained virtually unchanged (at the level of $2.3 \%$ ). 
Table 3

Impact of structural changes in FDI on indicators of macroeconomic security of Ukraine in 2006-2018

\begin{tabular}{|c|c|c|c|}
\hline \multirow{2}{*}{ Factorial features } & \multicolumn{3}{|c|}{ Dependent variable } \\
\hline & Unempl & $G D P \_p \_c$ & $G D P \_g \_r$ \\
\hline Number of observations & 13 & $\overline{13}$ & 13 \\
\hline Constant value & $\begin{array}{c}1,258^{* * *} \\
(0,088)\end{array}$ & $\begin{array}{c}-4,068^{* * *} \\
(0,645)\end{array}$ & $\begin{array}{c}1,688^{* * *} \\
(0,067)\end{array}$ \\
\hline invest_food_bev & - & $\begin{array}{c}2,238^{* * *} \\
(0,419)\end{array}$ & - \\
\hline invest_high_tech & $\begin{array}{c}-0,761^{\star \star \star} \\
(0,257)\end{array}$ & - & $\begin{array}{c}0,208^{\star \star \star} \\
(0,058)\end{array}$ \\
\hline invest_metall & $\begin{array}{c}-0,166^{\star * *} \\
(0,063)\end{array}$ & - & $\begin{array}{c}0,131^{* * *} \\
(0,031)\end{array}$ \\
\hline invest_telecom & - & $\begin{array}{c}1,976^{* * \star} \\
(0,417)\end{array}$ & $\begin{array}{c}0,173^{* * *} \\
(0,057)\end{array}$ \\
\hline invest_fin_insur & - & $\begin{array}{c}2,003^{* * *} \\
(0,294)\end{array}$ & - \\
\hline $\mathrm{R}$ & 0,81 & 0,96 & 0,84 \\
\hline $\mathrm{R}^{2}$ & 0,65 & 0,92 & 0,71 \\
\hline
\end{tabular}

* is a statistical error rate of $10 \%$;

** is a statistical error rate of $5 \%$;

$* * *$ is a statistical error rate of $1 \%$.

Source: Calculated by the authors using the data of the State Statistics Service of Ukraine.

The results of the regression analysis revealed a relatively weaker $\left(R=0.77, R^{2}=0.60\right)$ direct relationship between Consumer Price Index and the share of wholesale and retail investment in total FDI (Equation 1):

Consum $\mathrm{Pl}=1,521+0,656$ invest trade -

$-0,414$ invest_telecom $+0,188$ invest_high_tech.

In addition, during the period under review, there was a direct effect of the share of investments in high-tech industries in total FDI volumes on consumer price index, and the change in the share of investment in information and telecommunications activities has an inverse relationship with the dependent variable. The statistical error of this model does not exceed $5 \%$. However, the relationship between the dependent and independent variables is not strong enough (F-criterion $=4.54$ and slightly exceeds the value in Table). Consequently, a $60 \%$ increase in consumer prices is driven by the increase in the share of investments in wholesale and retail trade and in the share of high-tech industries in total FDI. 
Investing in the development of the trading network, modernization and creation of additional retail space in the conditions of unsaturated market results lead to higher prices for goods.

Increasing investment in high-tech industries in the conditions of declining physical production volumes in these industries is also driving up prices for these products. In particular, despite the fact that in Ukraine there is an increase in indices of industrial production in the manufacture of computers, electronic and optical products (from $86 \%$ in 2013 to $122.8 \%$ in 2018 (Industrial production indices by type of activity) ), there is a real downward trend in production in this area.

Thus, for the indicated period, the production of aeronautical or space navigation instruments and appliances (excluding compasses) decreased from 362 units. up to 75 units, electro-diagnostic apparatus (excluding electrocardiographs), n.e.c. - from 3003 units to 2629 units, network communications equipment (e.g. hubs, routers, gateways) for LANs and WANs and sound, video, network and similar cards for automatic data processing machines decreased from 50927 units to 2667 units (Manufacture of industrial products by types).

The inverse relationship revealed by our study between the consumer price index and the share of investment in information and telecommunications activities in total FDI indicates a positive impact of these investments on the development of a competitive market in this area. In this case, foreign direct investment contributes to lowering the price of information and telecommunications services by expanding networks and expanding the provision of these services.

\section{Conclusions}

The decrease in the level of investment security of Ukraine during 20062018 was caused by the deterioration of compliance of key indicators with the criteria of economic security. The most influential threats to the state's investment security in 2018 were conditioned by high depreciation of fixed assets at enterprises and insufficient investment in their reconstruction, as well as insufficient investment in high-tech industries. In addition to the degree of depreciation of fixed assets, the structure of foreign direct investment can be considered as a significant factor of investment security in Ukraine. The result of the study showed a high sensitivity of the integral indicator to the change in the share of investment in high-tech industries in total FDI volumes: if the value of this indicator is increased by $1 \%$ the figure increases by $0.165 \%$, all other things being equal.

Confirmation of the significant role of structural changes in foreign direct investment in the formation of Ukraine's economic security was obtained as a result of the regression analysis of data, using indicators of macroeconomic security of the state and independent variables as indicators of the structure of foreign 

and impact on ukraine's economic security

direct investment in Ukraine in 2006-2018. The results of the regression analysis allow drawing the following conclusions.

1. The inverse dependence is found between the unemployment rate and such FDI indicators as the share of investment in high-tech industries and in metallurgical production. Increasing FDI in these industries should reduce unemployment, primarily through expanding production capacity and creation of jobs. Thus, the increase of the unemployment rate in Ukraine during 2006-2018 by $60 \%$ can be explained by the decrease in the share of high-tech industries and metallurgy in the structure of FDI. There is no link between unemployment rate and changes in the share of investments in wholesale and retail trade, food, beverage and tobacco, information and telecommunications, financial and insurance in total FDI.

2. There is a strong direct link between GDP per capita and independent variables that characterize the change in the share of investment in food, beverage and tobacco, information and telecommunications, financial activity and FDI insurance. GDP growth per capita in $2006-2018$ by $92 \%$ is driven by an increase in the share of investment in food industry, information and telecommunications activities, despite a slight decrease in the share of investment in financial activities and insurance.

3. The decline in GDP growth over the period $2006-2018$ by $70 \%$ can be explained by a decrease in the total FDI share of investment in the metallurgical industry and investment in high-tech industries, since there is a strong direct relationship between dependent and independent variables. An increase in the share of investment in information and telecommunications activities in total FDI over the period under study has to some extent slowed the pace of GDP decline in Ukraine.

4. There is no strong direct link between the Consumer Price Index and the share of investments in wholesale and retail trade, and in high-tech industries in FDI. The increase in consumer prices in Ukraine over the period of 2006-2018 by $60 \%$ is due to an increase in the share of investments in wholesale and retail trade and in the share of high-tech industries in total FDI. This is due to the fact that in the context of unsaturated markets and the decline in physical volumes of production of high-tech products, current level of investment in these areas does not ensure a decrease in consumer prices. The inverse relationship is found between the Consumer Price Index and the share of investment in information and telecommunication activities in the FDI structure, which confirms positive impact of these investments on the development of the specified sphere and benefits for consumers by increasing the scope of provision of relevant services. 


\section{References}

1. Kibitkin, A.I., Skotarenko, O.V. (2010). Econometric Methods of Assessment of Sensitivity of Economic System. MGTU Newsletter, No. 1, pp. 22-26.

2. Mokii, A.I., Hurnyak, I.L., Datsko, O.I. (2014). Institutional Factors for the Formation of Threats to Investment Security in Ukraine. Actual Problems of International Relations, Vol. 121, Part II, pp. 74-88.

3. Nikitenko D.V. (2017). State of Investment Security of Ukraine. Scientific Bulletin of the International Humanitarian University. Series: Economics and Management, Vol. 25 (1), pp. 96-102. Retrieved from: http://nbuv.gov.ua/ UJRN/Nvmgu_eim_2017_25(1)_23.

4. Order of the Ministry of Economic Development and Trade of Ukraine No. 1277 of October 29, 2013 «On Approval of the Guidelines for Calculating the Level of Economic Security of Ukraine». Retrieved from: http://www.me.gov.ua/Documents/List?Lang=enGB\&tag=MetodichniRekomendatsii

5. Order of the Ministry of Economy of Ukraine No. 60 of March 2, 2007 «On Approval of the Methodology for Calculating the Level of Economic Security of Ukraine». Retrieved from: http://www.expert-ua.info//

6. Palyvoda K.V. (2018). Problems of Formation of Attractive Investment Climate to Overcome Destructions in the Ukrainian economy. Economy and the State, No. 3, pp. 4-9. Retrieved from: http: //www.economy.in.ua/pdf/3_2018/ 3.pdf.

7. Pereverzeva, A.V. (2016). Assessment of the Current State of Attraction of Foreign Investments in the Economy of Ukraine. Bulletin of Zaporizhzhya National University, No. 1 (29), pp. 75-81.

8. Sharov O.M. (2015). The Issue of the Strategy of Attracting Foreign Direct Investment in the Context of Meeting the Interests of Economic Security of the State. Strategic priorities, No. 1 (34), pp. 41-50.

9. State Statistics Service of Ukraine. Capital Investments in Ukraine. Retrieved from: http://www.ukrstat.gov.ua.

10. State Statistics Service of Ukraine. Direct Investment (equity) in the Ukrainian Economy by the Types of Economic Activity (2010-2018). Retrieved from: http://www.ukrstat.gov.ua.

11. State Statistics Service of Ukraine. Gross Domestic Product (1990-2018). Retrieved from: http://www.ukrstat.gov.ua.

12. State Statistics Service of Ukraine. Industrial Production Indices by the Types of Activity. Retrieved from: http://www.ukrstat.gov.ua. 

and impact on ukraine's economic security

13. State Statistics Service of Ukraine. Production of Industrial Products by Types. Retrieved from: http://www.ukrstat.gov.ua/operativ/operativ2016/ pr/vr_rea_ovpp/vr_rea_ovpp_u/arh_vppv_u.html.

14. State Statistics Service of Ukraine. Registered Unemployment (2006-2018). Retrieved from: http://www.ukrstat.gov.ua.

15. State Statistics Service of Ukraine. Value of Fixed Assets (2000-2018). Retrieved from: http://www.ukrstat.gov.ua.

16. Tkalenko S.I. (2019). Strategy of Investment Security of the National Economy in the Conditions of the European Integration Vector of Development. State and regions. Series: Economics and Entrepreneurship, No. 2, pp. 6268. Retrieved from: http://nbuv.gov.ua/UJRN/drep_2019_2_13.

17. Tymoshenko, O.V., Liskovetska, T.P. (2017). Features and Prospects of Attracting Foreign Investments in Ukraine in the Context of Ensuring Economic Security of the National Economy. Business Inform, No. 9, pp. 87-92.

The article was received on March 192020. 